\title{
Musculoskeletal pain, profile and quality of life of individuals with sickle cell disease
}

\author{
Dor osteomuscular, perfil e qualidade de vida de indivíduos com doença falciforme
}

\author{
Daniela G. Ohara', Gualberto Ruas², Shamyr S. Castro², Paulo R. J. Martins³, Isabel A. P. Walsh²
}

\begin{abstract}
Background: Sickle cell disease is a prevalent condition in Brazil. Its clinical presentation includes vascular occlusion that result in ischemia, inflammation, dysfunctions, pain and chronic hemolysis, causing irreversible damage and compromising quality of life. Objective: The objectives of this study were to verify the relationship between musculoskeletal pain, from different body parts, with social economic characteristics and quality of life among individuals with sickle cell disease. Method: 27 individuals with sickle cell disease were interviewed with the use of a structured questionnaire with questions about personal, social, economic and cultural variables, the Nordic musculoskeletal symptoms questionnaire and the SF-36 Health Survey. Data were analyzed descriptively using frequencies and percentages. The inferential Chi-Square test was used for dichotomous variables and the Student t- test for continuous variables, with a significance of $5 \%$. A logistic regression was performed using all variables that correlated with pain as dependent variables. Results: The mean age was 31.77 years, predominantly male, black, registered active employment, with average education and income up to three minimum wages. The regions most affected by pain were hip/limbs, chest, lower back and arms. Physical Functioning from the SF-36 had the highest score and mental health the lowest score. Musculoskeletal pain was present in the arms, chest and lower back. Social Functioning was not associated with pain, indicating the influence of other factors. Arm pain was more frequent in black individuals and those with low education. Conclusion: Body pain was associated with race and education and all pain areas were associated with the physical components of the SF-36. Pain was significantly associated with vitality and mental health components of the SF-36.
\end{abstract}

Keywords: sickle cell disease; pain; physical therapy; quality of life.

\section{Resumo}

Contextualização: As doenças falciformes constituem um grupo frequente no Brasil. Suas alterações ocasionam vaso-oclusão, resultando em isquemia, inflamação, disfunções, dor e hemólise crônica, gerando danos irreversíveis, comprometendo a qualidade de vida. Objetivo: Verificar a relação entre a dor osteomuscular, considerando sua localização corporal, e características sociais, econômicas e de qualidade de vida em indivíduos com doença falciforme. Método: Foram coletadas informações pessoais, sociais e econômicas, além de dados do Questionário Nórdico de Sintomas Osteomusculares (QNSO) e Short Form 36 em 27 indivíduos. Os dados foram analisados descritivamente por meio de frequências e porcentagens. A análise inferencial usou o teste do qui-quadrado (variáveis dicotômicas) e $t$ de Student (variáveis contínuas), com significância de $5 \%$. Análises de regressão logística utilizaram como variáveis dependentes cada uma das que se relacionaram com dor. Resultados: A média de idade foi de 31,77 anos, predominando sexo masculino, negros, emprego ativo, escolaridade média e rendimento inferior a três salários mínimos. Quadril/membros inferiores, região dorsal, lombar e braços foram mais acometidos pela dor. A capacidade funcional apresentou o maior valor, e saúde mental, o menor. Aspectos físicos foram comprometidos pela dor nos braços, coluna dorsal e lombar. Aspectos sociais não se associaram com a dor, indicando influência de outros fatores. A dor nos braços foi mais frequente entre os negros e os com baixa escolaridade. Conclusão: A dor nas regiões corporais analisadas relacionou-se com a raça e a escolaridade e com todos os domínios referentes ao componente físico do SF-36. Os componentes vitalidade e saúde mental apresentaram associação significativa com a dor.

Palavras-chave: anemia falciforme; dor; fisioterapia; qualidade de vida.

Received: 02/26/2012 - Revised: 05/02/2012 - Accepted: 05/18/2012

${ }_{1}$ Physical Therapist, Uberaba, MG, Brazil

${ }^{2}$ Department of Applied Physical Therapy, Institute of Health Sciences (ICS), Universidade Federal do Triângulo Mineiro (UFTM), Uberaba, MG, Brazil ${ }^{3}$ Department of Medicine, ICS, UFTM, Uberaba, MG, Brazil

Correspondence to: Daniela Gonçalves Ohara, Rua Felipe Achê, 447, Bairro Boa Vista, CEP 38070-030, Uberaba, MG, Brasil, e-mail: dani_ohara@hotmail.com 


\section{Introduction : $:$.}

Sickle cell disease comprises a group of genetic conditions that are between the most common in Brazil and other countries. It is characterized by a mutation in the $\beta$ chain of the hemoglobin gene, changing its normal structure $(\mathrm{HbA})$ to a $\mathrm{S}$ (HbS) or even a HbSS, a HbSC, a S-thalassemia and other less incident types ${ }^{1,2}$.

In Brazil, the law No. 1.391/GM developed by the National Health System, established the guidelines for the National Policy of Comprehensive Healthcare for People with Sickle Cell Disease and other hemoglobinopathies, with the following resolutions: creation of a national registry of this population, comprehensive healthcare through a multidisciplinary team, training of professionals for the promotion of permanent learning, promotion of access to information and genetic counseling to families and people with the condition or sickle cell trait, access to essential medicines and stimulation of research to improve quality of life ${ }^{3}$.

The HbS presents with different chemical characteristics and its functions are maintained under normal oxygenation. However, in situations of absence or reduced oxygen tension, the HbS undergoes polymerization changing its morphology and transforming into a sickle shape (sickling) resulting in ischemia, inflammation, disorders, pain and also chronic hemolysis that generates irreversible damage to various tissues and organs ${ }^{2,4-6}$.

Pain crises in this patient population are frequent and factors contributing to this process are: cold exposure, intense physical effort, hypoxia, dehydration, infections and general trauma ${ }^{2,6}$. Generally, these crises are the first manifestation of this disease and are considered the primary reason for the high rates of hospitalizations. Pain can occur in the extremities, spine and abdominal regions, negatively impacting quality of life ${ }^{7-8}$. Thus, chronic pain is considered a serious public health problem, taking into consideration that its treatment requires distinct interventions emphasizing pain reduction and the ability to perform self-care activities ${ }^{9}$.

Several studies examined pain and quality of life in patients with sickle cell disease ${ }^{10-20}$. However, studies evaluating pain on specific body regions, especially in the musculoskeletal system (bones, joints, muscles, or surrounding structures) were not found in the literature.

While individuals should be considered as a whole, factors related to pain location and its influence on quality of life must be taken into consideration when charting goals for a multidisciplinary health care, particularly physical therapy, which may have an important role in reducing pain crises, recurrent hospitalizations, morbidity and improving general mobility, fitness endurance and quality of life ${ }^{8}$.

The objective of this study was to investigate the relationship between musculoskeletal pain of different body regions and social, economic and quality of life characteristics of individuals with sickle cell disease.

\section{Method $: \because$.}

\section{Study type and population}

This study was an exploratory observational cross sectional cohort study with a quantitative methodology.

The convenience sample was recruited by selecting individuals over 18 years, through the assessment of records from the Regional Blood Bank of Uberaba city (HRU), MG, Brazil and the Regional Association of Sickle Cell Disease in Uberaba (ARFA), totaling 65 individuals. Of these, 38 were not included because they refused to participate, were not able to be contacted due to a change in contact information (phone and address) or because they had difficulty in understanding or answering the questionnaires. The study included 27 individuals who met the inclusion criteria: age over 18, diagnosis of sickle cell disease, hemodynamic and clinical stability, without painful crises at the time of assessment, who agreed to participate and signed an informed consent form.

Data collection was conducted from July to December 2011.

\section{Procedure for data collection}

After surveying the records of the HRU and ARFA and patients were identified, the patients upcoming medical appointments at the HRU was tracked, so they could be approached and respond to the questionnaires.

We proceeded to data collection through individual interviews, conducted in a reserved room by a previously trained physical therapist. To maintain confidentiality, the questionnaires were numbered.

\section{Tools for data collection}

To assess the profile of this population, a semi-structured questionnaire was constructed and included questions related 
to gender, age, schooling, occupation, monthly income and medical history.

The Nordic Musculoskeletal Questionnaire (QNSO) ${ }^{21}$ was used to assess musculoskeletal pain. The questionnaire was developed with the aim to standardize the assessment of musculoskeletal symptoms and to facilitate comparison between studies. The questionnaire has been translated into several languages over the last decade. It consists of multiple choice or binary choice questions about musculoskeletal symptoms of nine body regions over the 12 months and seven days preceding the interview. The questionnaire has been validated for use in Brazil ${ }^{22}$.

Quality of life was assessed using the SF-36 Health Survey translated and validated in Brazil by Ciconelli et al. ${ }^{23}$. It is a generic questionnaire that allows comparisons between different diseases and different treatments. It considers the perception of individuals regarding their own health and their most representative aspects. It is multidimensional, consisting of 36 items encompassed in eight domains that assess both negative aspects of health (disease and illness) and positive aspects (welfare). The answers are transformed into scores from 0 to 100 for each component, in which zero corresponds to the worst level of quality of life and 100 to the best ${ }^{23}$.

\section{Database preparation}

Age was categorized into three age groups: 19-30 years, 31-42 years and $43-54$ years as it was not normally distributed. Race was divided into white, black and brown; schooling, into low (elementary school), mean (high school) and high (higher education) and household income into less than three, three to six and more than six minimum wages.

The presence of pain by region, assessed by the QNSO was coded into the categories: "not and rarely" and "often and always", creating a new dichotomous variable, both for the last seven days and for the last 12 months.

\section{Data analysis}

Data were analyzed descriptively by means of absolute numbers, frequencies and percentages. The inferential analysis was performed using the chi-square test for dichotomous variables and the Student $\mathrm{t}$ test for continuous variables, respecting the normality of the variables, with significance of 5\%. Logistic regression analyses were performed using as dependent variables all variables found to be associated with pain. The method used was backward stepwise elimitation, in which the variables that were significant in the inferential analysis (independent) were placed all together in the model, being removed one by one. The variables that had a p-value between 0.20 and 0.05 were retained in the regression models for adjustment effects. The significance adopted for the model and for the variables was $5 \%$. The statistical software used was Stata 9.1.

The inferential and the logistic regression analyses were performed only for pain over the previous 12 months, considering that pain crises are frequent in this condictiont ${ }^{2,7}$ and that results based on a longer period could better explain its impact on quality of life.

\section{Legal aspects of the research}

The project was approved by the Committee of Ethics in Research of the Universidade Federal do Triângulo Mineiro (UFTM), Uberaba, MG, Brazil, under Protocol n 1818. The subjects were informed about the objectives and methodology of the study and signed an informed consent, according to the Resolution no 196 of October 10, 1996, of the National Health Council.

\section{Results $: \therefore$}

The study included 27 patients with sickle cell disease. From these, $85.20 \%$ were HbSS; $7.40 \%$ were HbSC and $7.40 \%$ were $\mathrm{HbS} \beta$. The mean age was 31.77 years $(\mathrm{SD} \pm 1.87)$, with a predominance of males (55.56\%) and blacks (59.26\%); 37.04\% had active formal employment and $59.1 \%$ had a mean schooling and low income (74.07\% lower than three minimum wages).

The mean SF-36 component socres are presented in Figure 1.

All subjects reported pain in the previous 12 months and $81.5 \%$, in the previous seven days in at least one body region. The results of the distribution of pain by body regions are shown in Table 1. The highest incidence of pain was in the hip/ lower limbs, followed by the thoracic spine, lumbar spine and arms, both in the previous 12 months and seven days.

The results of significant associations $(\mathrm{p}<0.05)$ and $\mathrm{p}<0.20$ found in the inferential analysis are described in Table 2 and 3.

Table 4 shows the results of logistic regression analysis.

It appears that all physical components of the SF-36 (Physical Functioning, Bodily Pain, Role-Physical and General Health) were significantly decreased due to pain, while, from the four mental components (mental health, Role-emotional, 
vitality and Social Functioning) the result were significant only for vitality and mental health.

The Physical Functioning component of the SF-36 was the one with the lowest impairment (score 86.85) and was influenced by pain in the neck/cervical region, shoulders and forearms. The Social Functioning component was between the most affected (score 50.46), however it was not significantly associated with pain in any of the studied regions. The component of mental health was the most affected in this study (48.29), being influenced by pain in the shoulders and arms.

Pain in the arms were significantly associated with race (blacks had more pain), schooling (individuals with low education had more pain) and a reduction in the domains of RolePhysical and Mental Health of the SF-36. Regression analysis revealed that race, schooling and Role-Physical of the SF-36 were also affected by pain in this region.

\section{Discussion $: \because$.}

The mean age in this study was 31.77 years $(\mathrm{SD} \pm 1.87)$, revealing the low life expectancy that individuals suffering from this condition are likely to have. According to Alves ${ }^{24}, 78.6 \%$ of

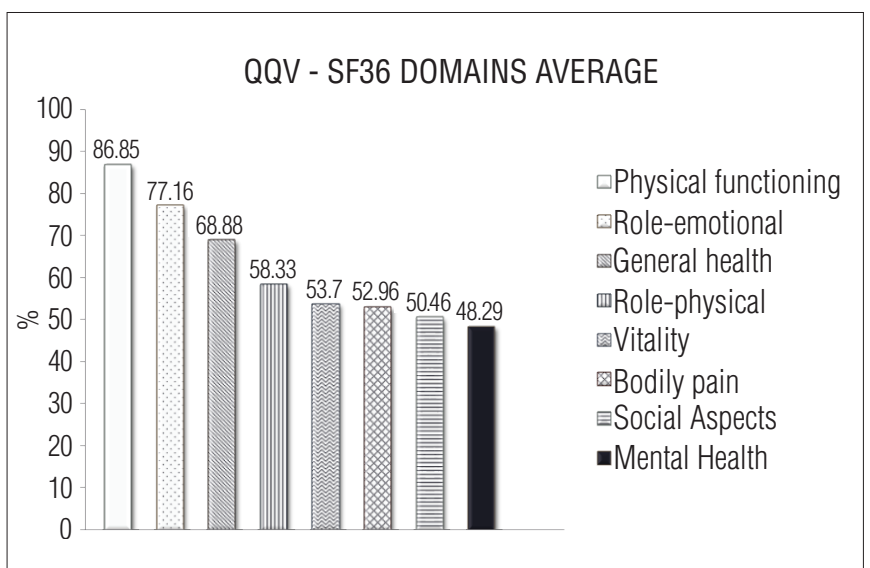

Figure 1. SF36-Health Survey domains average results.
Table 2. Association between personal, social, economic and cultural characteristics, SF-36 components and the presence of pain upper extremity pain on the previous 12 months.

\begin{tabular}{|c|c|c|}
\hline Body regions & & t 12 months (p) \\
\hline \multirow{4}{*}{ Shoulders } & Physical functioning & $0.0005^{\star}$ \\
\hline & Vitality & $0.0181^{*}$ \\
\hline & Role-emotional & $0.0911^{\star \star}$ \\
\hline & Mental health & $0.0448^{*}$ \\
\hline \multirow{6}{*}{ Arms } & Race & $0.009^{*}$ \\
\hline & Education & $0.019^{\star}$ \\
\hline & Role-physical & $0.0276^{\star}$ \\
\hline & Bodily pain & $0.0713^{\star \star}$ \\
\hline & General health & $0.1484^{* *}$ \\
\hline & Mental health & $0.0189^{*}$ \\
\hline \multirow{5}{*}{ Forearm } & Physical functioning & $0.0101^{*}$ \\
\hline & General health & $0.1934^{\star \star}$ \\
\hline & Vitality & $0.0264^{*}$ \\
\hline & Social functioning & $0.1986^{\star \star}$ \\
\hline & Role-emotional & $0.1903^{* *}$ \\
\hline
\end{tabular}

${ }^{*} p<0.05 ;{ }^{* *} p<0.20$

Table 3. Association between personal, social, economic and cultural characteristics, SF-36 components and the presence of pain on the spine and lower lombs over the previous 12 months.

\begin{tabular}{|c|c|c|}
\hline Bodyregions & & Last 12 months ( $p$ ) \\
\hline \multirow{5}{*}{ Neck/Cervical spine } & Physical functioning & $0.0001^{*}$ \\
\hline & General health & $0.0891^{* *}$ \\
\hline & Vitality & $0.1742^{* *}$ \\
\hline & Role-emotional & $0.1086^{\star *}$ \\
\hline & Mental health & $0.0985^{\star *}$ \\
\hline \multirow{3}{*}{ Dorsal } & Role-physical & $0.0099^{\star}$ \\
\hline & Bodily pain & $0.0029^{*}$ \\
\hline & Mental health & $0.0365^{*}$ \\
\hline \multirow{4}{*}{ Lowerback } & Role-physical & $0.0008^{*}$ \\
\hline & General health & $0.0014^{\star}$ \\
\hline & Role-emotional & $0.0976^{\star *}$ \\
\hline & Mental health & $0.0650^{* *}$ \\
\hline \multirow{6}{*}{ Hip /Lowerlimbs } & Physical functioning & $0.1775^{\star \star}$ \\
\hline & Role-physical & $0.1757^{\star \star}$ \\
\hline & Bodily pain & $0.0342^{*}$ \\
\hline & General health & $0.1927^{\star \star}$ \\
\hline & Vitality & $0.1119^{\star \star}$ \\
\hline & Mental health & $0.0755^{\star \star}$ \\
\hline
\end{tabular}

${ }^{*} \mathrm{p}<0.05 ;{ }^{*} \mathrm{p}<0.20$

Table 1. Pain distribution during the previous 12 months and the previous seven days.

\begin{tabular}{|c|c|c|c|c|c|c|c|c|}
\hline \multirow{3}{*}{ Body regions } & \multicolumn{4}{|c|}{ Previous 12 months } & \multicolumn{4}{|c|}{ Previous seven days } \\
\hline & \multicolumn{2}{|c|}{ No pain } & \multicolumn{2}{|c|}{ Presence of pain } & \multicolumn{2}{|c|}{ No pain } & \multicolumn{2}{|c|}{ Presence of pain } \\
\hline & $\mathrm{n}$ & $\%$ & $\mathrm{n}$ & $\%$ & $\mathrm{n}$ & $\%$ & $\mathrm{n}$ & $\%$ \\
\hline Neck/Cervical spine & 23 & 85.19 & 4 & 14.81 & 21 & 77.78 & 6 & 22.22 \\
\hline Shoulders & 22 & 81.48 & 5 & 18.52 & 22 & 81.48 & 5 & 18.52 \\
\hline Arms & 16 & 59.26 & 11 & 40.74 & 18 & 66.67 & 9 & 33.33 \\
\hline Elbows & 24 & 88.89 & 3 & 11.11 & 23 & 85.19 & 4 & 14.81 \\
\hline Forearms & 23 & 85.19 & 4 & 14.81 & 23 & 85.19 & 4 & 14.81 \\
\hline Wrist /hand / fingers & 22 & 81.48 & 5 & 18.52 & 22 & 81.48 & 5 & 18.52 \\
\hline Toracic spine & 13 & 48.15 & 14 & 51.85 & 17 & 62.96 & 10 & 37.04 \\
\hline Lower back & 14 & 51.85 & 13 & 48.15 & 18 & 66.67 & 9 & 33.33 \\
\hline Hip /Lower limbs & 11 & 40.74 & 16 & 59.26 & 13 & 48.15 & 14 & 51.85 \\
\hline
\end{tabular}


Table 4. Logistic regression analysis between personal, social, economic and cultural characteristics, SF-36 components and the presence of pain over the previous 12 months.

\begin{tabular}{|c|c|c|}
\hline Body regions & $\begin{array}{c}\text { Components Regression } \\
\text { Model }\end{array}$ & $p$ \\
\hline Neck/Cervical spine & & 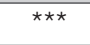 \\
\hline \multirow{3}{*}{ Shoulders } & Constant & 0.0670 \\
\hline & Vitality & 0.1750 \\
\hline & Physical functioning & 0.0450 \\
\hline \multirow{4}{*}{ Arms } & Constant & 0.0100 \\
\hline & Education & 0.1080 \\
\hline & Race & 0.1580 \\
\hline & Role-physical & 0.1630 \\
\hline \multirow{3}{*}{ Forearm } & Constant & \multirow{3}{*}{$* * *$} \\
\hline & Vitality & \\
\hline & Physical functioning & \\
\hline \multirow{3}{*}{ Dorsal } & Constant & 0.9410 \\
\hline & Mental health & 0.1220 \\
\hline & Bodily pain & 0.0210 \\
\hline \multirow{3}{*}{ Lowerback } & Constant & 0.8220 \\
\hline & General health & 0.0460 \\
\hline & Role-physical & 0.0640 \\
\hline Hip/Lowerlimbs & & $\star \star *$ \\
\hline
\end{tabular}

all deaths in individuals with sickle cell disease occur before 29 years of age, demonstrating its severity and lethality.

The highest prevalence of the condition in black individuals found in this study is in agreement with what has been reported in the literature. The condition is thought to be of African origin and been brought to the Americas through the forced immigration of slaves. In Brazil, black and brown individuals are more oftenly affected, although it occurs at a lower frequency in white individuals due to miscegenation ${ }^{1}$.

The results demonstrated that $100 \%$ of the subjects experienced pain on at least one body region in the previous 12 months and $81.5 \%$ in the previous seven days. A previous study also conducted in the same recruitment site (HRU) ${ }^{25}$ showed that the most prevalent cause of health care consultation $(64.4 \%)$ were pain crises.

Male individuals were predominant in our sample, perhaps due to the small sample size. Still, there was no statistically significant difference between genders regarding pain. Smith et al. ${ }^{18}$ conducted a study that assessed pain in adults with sickle cell disease and also found no difference in gender.

Pain was more common on the hip/lower limbs, followed by the thoracic spine, lumbar spine and arms. Taylor et al. ${ }^{26}$ conducted a literature review on the multiple dimensions of chronic pain in adults with sickle cell disease and also found that the region mostly affected by chronic pain was the hip (the variation in the studies ranged from $60 \%$ to $100 \%)$, followed by the spine. Silva and Marques ${ }^{17}$ stated that the femur and the tibia were among the areas most frequently affected by pain symptoms and Felix, Souza and Ribeiro ${ }^{15}$ showed that the lower limbs were among the areas most commonly affected by pain.

The inferential analysis indicated a significant association between pain in the thoracic spine, hip/lower limbs and greater impairment in bodily pain assessed using the SF-36. This pain domain assesses pain intensity and its extent or interference with activities of daily living (ADL) ${ }^{23}$. These results can be explained, at least in part, by the study of Ballas ${ }^{14}$, which indicated that many complications of sickle cell disease, such as avascular necrosis and lower limb ulcers, could also have been involved with the mechanisms of chronic pain, , given that $44 \%$ of the sample had or would have been affect by sickle ulcers throughout their lives. Furthermore, according to Daltro et al. ${ }^{27}$ the prevalence of osteonecrosis of the femoral head increases with increasing age.

In sickle cell disease, deformities can occur mostly as a result of recurrent vascular occlusion, which can lead to bone infarcts. In the spine, the sites of bone infarction can reach central regions of the vertebral plateaus causing excessive growth in adjacent regions and a depression of the central plateaus, resulting in a characteristic deformity of the vertebral bodies known as "H vertebra" 28,29 .

These infarcts can also reach the epiphyseal regions of bones. In fact half of the individuals under 35 years of age suffering from sickle cell disease have osteonecrosis of the hip. This is another factor predisposing a patient to the presence of pain in this region. This osteonecrosis can occur in any bone, however it is more common in the humerus and femur ${ }^{29,30}$ and is more prevalent in men and those with older age. Furthermore, the development of ulcers in the lower limbs, specifically the malleoli are common, causing severe pain and difficult scarring ${ }^{31}$.

Considering that functional capacity includes the performance of daily activities, such as capacity for self-care, dressing, bathing and climbing stairs ${ }^{23}$, the findings that functional capacity were influenced by pain in the neck/ cervical region, shoulders and forearms, were to be expected. Shoulder pain is known to influence the whole upper limb mobility and strength, given the rise in overload of the other structures such as the cervical region/neck ${ }^{32}$. The Physical Functioning component of the SF-36 was found to have the highest value, indicating that despite pain, individuals could still perform their daily activities. This can be explained by the fact that many individuals with sickle cell disease have a passive role in their health care influenced by the lack of guidance and knowledge of 
their rights, taking the pain as a normal part of the disease. Also, Lobo, Marra and Silva ${ }^{16}$ reported that, although patients with sickle cell disease suffers intense pain, many continue performing their activities normally, without showing the expected image of intense pain that those without the disease would demonstrate in this situation.

The role-physical component of the SF-36 that includes the impact of physical health on performance of daily activities and/or professional activities ${ }^{23}$, was significantly compromised by pain in the arms, thoracic and lumbar spine. In many occupational situations, organizational and job physical requirements, force workers to perform their functions in an way that overloads specific body structures ${ }^{33}$. Thus, these results can be directly associated to the professional activities performed by these individuals, since most have active employment. Considering the study by Ivo and Carvalho ${ }^{34}$ that investigated the behavior of patients with sickle cell disease and identified the presence of joint deformities in half of the sample studied resulting in altered gait and posture, we could assume that the patients in this study would have been affect similarly and therefore be prone to increased overload and triggering and perpetuation of pain in these regions.

The low schooling was significantly associated with pain in the arms, indicating that, in addition to aspects related to quality of life, it can help to understand the interference of pain in work activities. According to Wijnhoven, de Vet and Picavet ${ }^{35}$, low schooling and occupations that include excess physical effort (housemaid, construction workers, general services, among others) are risk factors for the development of pain. Many individuals in the present study performed activities such as housemaids, general services and car washer, predisposing them to pain in the arms.

The pathophysiological changes of vascular occlusion could explain the fact that aspects related to the assessment of vitality, which encompasses both the energy level and fatigue $^{23}$, were influenced by the pain in the shoulders and forearms. These blood vessel blockages are more common in shoulders, in the region of the long bones and vertebrae, causing pain, decreased concentration of oxygen and therefore, fatigue ${ }^{17}$.

Strickland et al. ${ }^{20}$ found that the difficulty in dealing with recurrent painful conditions adversely affects the quality of life of individuals with sickle cell anemia in the physical, emotional and social aspects.

In this study, the social functioning component of the SF-36 that examine whether the integration of the individual in social activities was affected by their health problems $^{23}$ showed significant impairment (score 50.46); while, for the component role-emotional, that deal with the limitations on the type and amount of work and how these limitations hamper the work and performance of daily life activites ${ }^{23}$, the scores were lower (score 71.16). However, they were not significantly associated with pain in any of the regions studied. These results suggest that these domains are affected by other components of the disease other than pain. The occupational instability that is common in this patient population due to the constant need for sick leave due to treatment ${ }^{34}$, and the associated financial issues, could explain these results, since in the present study, the majority of individuals showed active formal employment and mean schooling, while income remained less than three minimum wages.

It should be added that the body development of this patient group is slower, not corresponding to their chronological age, which can cause a decrease in self-esteem, associated with social isolation ${ }^{34}$.

McClishet et al. ${ }^{36}$ assessed quality of life of 308 individuals with sickle cell disease using the SF-36 and found that the mental health component, including issues related to anxiety, depression, abnormal behavior or emotional imbalance and psychological welfare ${ }^{23}$, was the only that did not show worse scores than the general population. The authors explained this event as a result of increased social support, absence of other stressors or behavior change in face of their mental health, adapting to conditions that the chronic disease provide. In contrast, in the present study, the domain related to mental health was the most affected (score 48.29). This fact can be explained by the individual's knowledge of the disease severity and its commitments, generating insecurity about the near future and fear of imminent death ${ }^{34}$. Added to this, the pain crises and frequent hospitalizations that occurred in the course of their lives can cause anxiety, depression, aggressive behavior and fear ${ }^{10}$. In addition, this component was also influenced by pain in the shoulders and arms which may be associated with work activities that required greater physical effort. A decrease in the performance of work activities due to pain may generate a feeling of inferiority and low self-esteem, reflecting directly in mental health, which may be one more justification for the low mental health value reached.

There are some limitations to this study. Although the QNSO has proved to be an appropriate tool to assess pain in specific regions in this population, the fact that it was originally developed to assess pain in Work-Related Musculoskeletal Disorders (WMSDs) and that there were no other studies in the literature using this instrument in this population, no comparisons were performed. Furthermore, 
studies that have studied the association of pain with quality of life usually do not separate pain by body regions, making it difficult to discuss this research with the scientific literature. Thus, new multicenter studies and with larger samples should be encouraged, in order to allow comparisons with this and others studies, as well as provide a better understanding of pain in this condition.

\section{Conclusion $: \because$.}

Pain was one of the most common symptoms of patients with sickle cell disease, as all patients in this study reported pain in at least one body region.

The physical aspects of quality of life were influenced by pain from different body regions. Pain in the upper limbs contributed to reduced Physical Functioning, Vitality, RolePhysical and Mental Health and was also associated with race (blacks had more pain) and schooling (low schooling was associated with pain). Pain on the spine and the lower limbs, contributed to a reduction in the scores of Physical
Functioning, Role-Physical, General Health, Mental Health and Bodily pain components of the SF-36. Physical functioning, role-physical, schooling and race were associated with pain in the upper limbs, while the pain on the thoracic and the lumbar spine were associated with bodily pain and Role-Physical.

It is hoped that the results of this research will contribute to the planning of interventions not only in rehabilitation, but mostly preventive and in health promotion through proper multidisciplinary care. In physical therapy, the data will support decision making, allowing a service rich in resources and techniques for prevention and musculoskeletal rehabilitation, with reduction and improvement of pain, recovery of mobility, improvement of resistance to efforts, allowing individuals greater skill in performing the ADL and work activities.

\section{Acknowledgments : :}

To the Secretaria de Educação Superior do Ministério da Educação, to the HRU and to the ARFA, MG, Brazil.

\section{References $: \because$.}

1. ANVISA. Manual de diagnóstico e tratamento de doença falciforme. Brasília: [s.d.]; 2002.

2. Brasil. Ministério da Saúde. Secretaria de Atenção à Saúde. Departamento de Atenção Especializada. Manual de eventos agudos em doença falciforme. Ministério da Saúde, Secretaria de Atenção à Saúde, Departamento de Atenção Especializada. Brasília: Editora do Ministério da Saúde; 2009

3. Brasil. Ministério da Saúde. Portaria GM/MS no 1391, de 16 de agosto de 2005. Institui no âmbito do Sistema Único de Saúde, as diretrizes para a Política Nacional de Atenção Integral às Pessoas com Doença Falciforme e outras Hemoglobinopatias. Diário Oficial da União, Braśilia (DF), p. 40, col. 2, 2005

4. Brasil. Ministério da Saúde, Secretaria de Atenção à Saúde, Departamento de Atenção Especializada. Manual de Educação em Saúde: autocuidado na Doença Falciforme. Brasília: Editora do Ministério da Saúde, 2008. 70 p

5. Machado RFP. Hipertensão arterial pulmonar associada à anemia falciforme. J Bras Pneumol. 2007;33(5):583-91.

6. Moreira GA. Repercussões respiratórias da anemia falciforme. J Bras Pneumol. 2007;33(3):xviii-xX.

7. Brasil. Ministério da Saúde. Secretaria de Atenção à Saúde. Departamento de Atenção Especializada. Manual de condutas básicas na doença falciforme. Brasilia: Editora do Ministério da Saúde; 2006.

8. Silva IA. Atuação fisioterapêutica na anemia falciforme. Lato \& Sensu. 2003;4(1):3-5.

9. Carpenter L, Baker GA, Tyldesley B. The use of the canadian occupational performance measure as an outcome of a pain mangement program. Can J Occup Ther. 2001;68(1):16-22.

10. Santos ARR, Miyazaki MCO. Grupo de sala de espera em ambulatório de doença falciforme. Rev Bras Ter Comport Cogn. 1999;1(1):41-8.
11. Filha ACS, Barros FNS, Carvalho FJR, Souza JB, Picão VS. Mensuração da dor em pacientes portadores de anemia falciforme. Revista Digital de Pesquisa CONQUER da Faculdade São Francisco de Barreiras. 2008;3:1-8.

12. Asnani MR, Lipps GE, Reid ME. Utility of WHOQOL-BREF in measuring quality of life in sickle cell disease. Health Qual Life Outcomes. 2009;7:75.

13. Galiza Neto GC, Pitombeira MS. Aspectos moleculares da anemia falciforme. J Bras Patol Med Lab. 2003;39(1):51-6.

14. Ballas SK. Pain management of sickle cell disease. Hematol Oncol Clin North Am. 2005;19(5):785-802.

15. Felix AA, Souza HM, Ribeiro SBF. Aspectos epidemiológicos e sociais da doença falciforme. Rev Bras Hematol Hemoter. 2010;32(3):203-8.

16. Lobo C, Marra VN, Silva RMG. Crises dolorosas na doença falciforme. Rev Bras Hematol Hemoter. 2007;29(3):247-58.

17. Silva DG, Marques IR. Intervenções de enfermagem durante crises álgicas em portadores de anemia falciforme. Rev Bras Enferm. 2007;60(3):327-30.

18. Smith WR, Penberthy LT, Bovbjerg VE, McClish DK, Roberts JD, Dahman B, et al. Daily assessment of pain in adults with sickle cell disease. Ann Intern Med. 2008;148(2):94-101.

19. Pereira SAS, Cardoso CS, Brener S, Proietti ABFC. Doença falciforme e qualidade de vida: um estudo da percepção subjetiva dos pacientes da Fundação Hemominas, Minas Gerais, Brasil. Rev Bras Hematol Hemoter. 2008;30(5):411-6

20. Strickland OL, Jackson G, Gilead M, McGuire DB, Quarles S. Use of focus groups for pain and quality of life assessment in adults with sickle cell disease. J Natl Black Nurses Assoc. 2001;12(2):36-43. 
21. Kuorinka I, Jonsson B, Kilbom A, Vinterberg H, Biering-Sørensen F, Andersson G, et al Standardised Nordic questionnaires for the analysis of musculoskeletal symptoms. Appl Ergon. 1987;18(3):233-7.

22. Pinheiro FA, Tróccoli BT, Carvalho CV. Validação do questionário nórdico de sintomas osteomusculares como medida de morbidade. Rev Saúde Pública. 2002;36(3):307-12.

23. Ciconelli RM, Ferraz MB, Santos W, Meinão I, Quaresma MR. Tradução para a língua portuguesa e validação do questionário genérico de avaliação de qualidade de vida SF-36 (Brasil SF-36). Rev Bras Reumatol. 1999;39(3):143-50.

24. Alves AL. Estudo da mortalidade por anemia falciforme. Inf Epidemiol SUS. 1996;5(4):45-53.

25. Martins PRJ, Moraes-Souza H, Silveira TB. Morbimortalidade em doença falciforme. Rev Bras Hemoter Hematol. 2010;32(5):378-83.

26. Taylor LEV, Stotts NA, Humphreys J, Treadwell MJ, Miaskowski C. A review of the literature on the multiple dimensions of chronic pain in adults with sickle cell disease. J Pain Symptom Manage. 2010;40(3):416-35.

27. Daltro G, Alencar DF, Sobrinho UB, Guedes A, Fortuna VA. Osteonecrose da cabeça femoral na anemia falciforme. Gazeta Médica da Bahia. 2010;80(3):29-32.

28. Almeida A, Roberts I. Bone involvement in sickle cell disease. Br J Haematol. 2005;129(4):482-90.
29. Lonergan GJ, Cline DB, Abbondanzo SL. Sickle cell anemia. Radiographics. 2001;21(4):971-94

30. Yanaguizawa M, Taberner GS, Cardoso FNC, Natour J, Fernandes ARC. Diagnóstico por imagem na avaliação da anemia falciforme. Rev Bras Reumatol. 2008;48(2):102-5.

31. Minniti CP, Eckman J, Sebastiani P, Steinberg MH, Ballas SK. Leg ulcers in sickle cell disease Am J Hematol. 2010;85(10):831-3.

32. Santos MC, Lancman S. Avaliação da função do ombro em técnicos de trânsito pelo protocolo de Constant-Murley. Fisioter Pesqui. 2008;15(3):259-65.

33. Picoloto D, Silveira E. Prevalência de sintomas osteomusculares e fatores associados em trabalhadores de uma indústria metalúrgica de Canoas - RS. Ciênc Saúde Coletiva 2008;13(2):507-16.

34. Ivo ML, Carvalho EC. Assistência de enfermagem a portadores de anemia falciforme, à luz do referencial de Roy. Rev Latinoam Enferm. 2003;11(2):192-8.

35. Wijnhoven HAH, de Vet HCW, Picavet HSJ. Explaining sex differences in chronic musculoskeletal pain in a general population. Pain. 2006;124(1-2):158-66.

36. McClish DK, Penberthy LT, Bovbjerg VE, Roberts JD, Aisiku IP, Levenson JL, et al Health related quality of life in sickle cell patients: the PiSCES project. Health Qual Life Outcomes. 2005;3:50. 